ANDRZEJ SZPULAK

Uniwersytet im. Adama Mickiewicza

\title{
Róża Wojciecha Smarzowskiego - portret miłości kulturowo zakorzenionej
}

Images

vol. XVII/no. 26

Poznań 2015

ISSN 1731-450x

\author{
Tadeusz Sobolewski: Co w Róży było dla pana \\ najważniejsze? Historia? \\ Wojtek Smarzowski: Miłość. Na temat Mazur \\ trafiłem przypadkiem, gdy dostałem scenariusz \\ Michała Szczerbica[1].
}

A zatem historia czy miłość? Tak w świetle tej wymiany zdań między krytykiem a twórcą może brzmieć pytanie o kluczowy temat Róży (2011) Wojciecha Smarzowskiego. Każda jednoznaczna odpowiedź na poziomie pogłębionej refleksji byłaby, rzecz jasna, uproszczeniem. Kluczy tematycznych do tego ważnego utworu jest bowiem kilka. W tym tekście wypadnie nam jednak przyjrzeć się bliżej tylko jednemu, właśnie temu, który wybrany został przez samego reżysera. Wyeksponowanie filmowego obrazu miłości grozi oczywiście popadnięciem w jednostronność, zawężeniem pola widzenia albo wręcz przyczynkarstwem, lecz takie zastrzeżenia powinny zostać na razie zawieszone. A to z tego powodu, iż - co postaram się wykazać - właśnie sposób ukształtowania obrazu miłości ma decydujący wpływ na odsłonięcie ukrytego pod sugestywną i widowiskową fasadą trochę niespodziewanego kodu kulturowego, w ramach którego formowany jest najistotniejszy przekaz tego filmu. Róża okazuje się bowiem czymś innym, niż się na pierwszy rzut oka wydaje.

Punktem wyjścia do podania w wątpliwość najbardziej oczywistych i rozpowszechnionych w recepcji krytycznej interpretacji Róży może być kwestia tożsamości tytułowej bohaterki, która to kwestia ma szczególne znaczenie dla kreacji wizerunku miłości.

$Z$ jednej strony los i dylematy mazurskiej wdowy po żołnierzu Wehrmachtu nie budzą wątpliwości. Jest ona kobietą osamotnioną, mającą za sobą nieskuteczną próbę ucieczki i doświadczenie wielokrotnego zgwałcenia przez czerwonoarmistów, odtrąconą przez własną wspólnotę, bezsilną wobec powtarzających się rabunków, borykającą się z nową wrogo nastawioną władzą. To sytuacja tyleż przerażająca, co częsta w mazurskich realiach roku 1945 . Odsyła ona ponadto tę postać w przestrzeń wykluczenia, cielesnej traumy, bezwzględnej walki o dominację i tej dominacji potwierdzanie, a więc ku dyskursom podręcznym i nierzadko wystarczającym dla współczesnych komentatorów.

[1] Rozmowa $z$ Wojtkiem Smarzowskim, reżyserem filmu „Róża”. Rozmawiał Tadeusz Sobolewski, „Gazeta Wyborcza” [online], 13 czerwca
2011 [dostęp: 12 lutego 2015], <http://wyborcza. pl/1,75475,9770704,Rozmowa_z_Wojtkiem_Smarzowskim_rezyserem_filmu_Roza_html $>$. 
Z drugiej jednak strony konstrukcja postaci wymyka się oczywistościom. Już sama jej zewnętrzność dezintegruje obraz jej tożsamości. Strój jest owszem mazurski, ale mowa już nie. To konsekwencja decyzji twórców, by bohaterka nie mówiła gwarą czy też nie stylizowała na nią polszczyzny literackiej, którą się posługuje. W ten sposób doprowadzono m.in. do wyraźnego oddzielenia postaci od grupy, do której miałaby przynależeć. Róża używa gwary mazurskiej tylko raz, gdy podczas bielenia ścian śpiewa ludową piosenkę. W innym momencie, gdy siedzą przed domem, opowiada Tadeuszowi o tutejszych zwyczajach i wierzeniach ludowych. Odtwarza ich ukryte znaczenia. Używa formy my, lecz w tych swoich wypowiedziach przypomina raczej kogoś w rodzaju wrośniętej w tę rzeczywistość polskiej nauczycielki czy bibliotekarki niż mazurską chłopkę, nawet jeśli miałaby być ona wyjątkowo oczytana (mężczyzna znajduje w jej domu francuską powieść wydaną $\mathrm{w}$ Warszawie w roku 1925). Jest w tym jej odsłanianiu miejscowych tajemnic odcień inteligenckiej fascynacji i dystansu.

Co znaczące, Róży nieomalże wcale nie widzimy w kontaktach ze społecznością wioski. Nikt jej nie odwiedza ani - poza dyskretnie działającym pastorem - nie pomaga. Do kościoła wchodzi spóźniona. Nie ma żadnej sceny dialogu między nią a kimś z sąsiadów. Niektórzy, szczególnie żona przywódcy lokalnej społeczności - Mateusza, Greta, reagują na nią z niechęcią, wypominając formę ratunku, jaką przyjęła podczas pobytu sowieckiego oddziału w swoim gospodarstwie - „dobrowolne” współżycie z dowódcą. Pojawiają się oni w jej domu, dopiero gdy spoczywa w trumnie. Jej mazurskość okazuje się więc problematyczna. Wydaje się bardziej deklarowana niż realnie odczuwalna. Bohaterka pod względem funkcjonalności fabularnej do niej przynależy, jednak to, co przesądzające w jej historii, rozgrywa się w innej przestrzeni, odnosi do innych, raczej nieplebejskich porządków.

$\mathrm{Na}$ ekranie pojawia się ona bowiem prawie wyłącznie w relacji z Tadeuszem, przybywającym do jej domu byłym akowcem, polskim inteligentem. Ta relacja będzie nas interesować w szczególny sposób, ale też jest ona dla odczytania filmu podstawowa. Można powiedzieć, że nie ma ona - w sferze konstrukcji filmowego świata - charakteru równoprawnego. Róża nie ma bardzo daleko posuniętej autonomii w rzeczywistości skupiającej się wokół historii Tadeusza. Oczywiście deficytu wewnątrzfilmowej autonomii nie należy utożsamiać z fabularną biernością - to dwie różne sprawy. Kiedy protagonistka odrzuca podpisanie deklaracji polskości albo gdy tuż przed śmiercią projektuje ślub swojej córki z głównym bohaterem, wtedy wszakże działa, wpływa na bieg zdarzeń. W tym ostatnim przypadku manifestuje się nawet coś, co w świetle naszych dalszych rozważań można by nazwać duchowym geniuszem kobiety, którego dzieła mężczyzna nie do końca rozumie, ale który przyjmuje. Tyle tylko, że my postrzegamy to właśnie z perspektywy mężczyzny i w odniesieniu do niego. Kamera od pierwszych do ostatnich sekund śledzi postać męską, opowiada o niej, jej doznaniach i jej przypadkach, które od pewnego momentu obracają się wokół Róży. 
A składają się one w bardzo wyrazistą, osobną, ale też bardzo polską historię. Były akowiec nie jest medium pozwalającym wejrzeć w uniwersum powojennej mazurskiej gehenny. To raczej on podporządkowuje owo uniwersum swojemu kulturowo zakorzenionemu widzeniu świata.

Jeśli już kamera pozostaje przy Róży, jak np. w nocnej scenie sprowadzenia córki ze strychu, to istotą tego ujęcia jest nasłuchiwanie odgłosów kroków mężczyzny i następujących potem kroków Jadwigi. Gdy widzimy Różę pozostającą $\mathrm{w}$ domu podczas rozminowywania pola, podśpiewującą pogodną piosenkę, to przecież obserwuje ona wtedy przez okno pracę mężczyzny i zszywa jego spodnie, by po chwili, gdy następuje wybuch, biec ku niemu i ekspresyjnie wyrazić wobec niego swoje emocje. Nawet we własnej społeczności pojawia się ona za pośrednictwem Tadeusza, gdy ten przywozi ziemniaki dla sąsiadów, albo razem z nim, gdy wchodzą do kościoła i siadają w ławce. Tragedię kobiety, jej cierpienie, chorobę i śmierć także możemy widzieć tylko tak, jak widzi je bohater[2]. Wraz z nim wkraczamy w środek napadu bandy dowodzonej przez Wasyla albo ataku bólu podczas wizyty ubeków. Nawet retrospekcje, pokazujące Różę w realiach sprzed kilku miesięcy, niewątpliwie oddziaływające samoistnie w związku ze swą przerażającą treścią i swoistą dramaturgią, umieszczone są $\mathrm{w}$ ramie relacji, którą przedstawia Tadeuszowi pastor, a potem sama bohaterka.

Pojawienie się, istnienie i odejście Róży jest kolejnym życiowym doświadczeniem Tadeusza, dlatego na ekranie widzimy ją ze względu na niego, w łączności z nim i z jego punktu widzenia. Najistotniejsza wewnętrzna konstrukcja jej postaci wpisuje się w sposób kreacji świata zgodny z tym, jak w polskiej kulturze opowiada się los bohaterów o charakterystyce byłego warszawskiego powstańca. Sceny gwałtów są tu bezpośrednim obrazem cierpienia kobiety, lecz w zdecydowanie większym stopniu są obrazem duchowego cierpienia nieomal bezradnego świadka - mężczyzny. W ostatecznym rachunku - uznając tytuł za nieco mylący - wypada więc w pierwszym rzędzie przyjrzeć się narracyjnemu centrum, jakim jest główny bohater, jego losy i jego widzenie świata i z tej perspektywy zobaczyć także Różę.

Zanim jednak do tego dojdzie, warto jeszcze expressis verbis sformułować generalną wątpliwość, rodzącą się po tym bardzo niepełnym spojrzeniu na tytułową bohaterkę. Powstaje bowiem pytanie, czy tak eksponowana w recepcji utworu sprawa Mazurów nie stanowi jedynie pewnego aspektu filmowych zdarzeń, atrakcyjnego, użytecznego, akceptowalnego dla opiniotwórczych odbiorców, komplikującego tropy, ale jednak - jeśli chodzi o znaczenie i głębię wyrazu - drugoplanowego? Czy pod ową mazurską powłoką nie kryje się przekaz ważniejszy, nie tyle nawet uniwersalizujący, ile dotyczący nieco innego problemu?

[2] Pisze o tym także Agnieszka Morstin, negatywnie waloryzując portret bohaterki jako obraz ofiary, która z rzadka bywa kobietą, a nie kobiety, która jest ofiarą. A. Morstin, Mocne filmy i głębokie kompleksy. „Róża”
Wojtka Smarzowskiego wobec „Jak być kochaną" Wojciecha J. Hasa, „Kwartalnik Filmowy”, nr 77-78, 2012, s. 206. 
Można mieć nadzieję, iż właśnie analiza historii Tadeusza poprowadzi m.in. ku w miarę przekonującej odpowiedzi.

A zaczyna się ta historia $\mathrm{w}$ trakcie powstania warszawskiego, a więc w czasoprzestrzeni, która dla Polaków konotuje potężną i nośną symbolikę tyrtejską i martyrologiczną zarazem, pełni funkcję jednej z najbardziej rozpowszechnionych i najsilniej oddziaływających figur pamięci. Trwająca ledwie minutę sekwencja powstańcza staje się siłą rzeczy syntetyzującym skrótem. Odnosi się do tej części obrazu warszawskiego zrywu, którą można zdefiniować jako doświadczenie klęski. Nie ma już dynamiki, nadziei, poczucia wolności, nie ma nawet heroicznej walki czy choćby upokarzającej ucieczki kanałami. Pozostaje tylko gwałt - znak bezwarunkowej dominacji oraz śmierć - także śmierć miasta, wyrażana przez zwały gruzów i płomienie pożarów.

Tadeusz od pierwszych sekund musi pełnić rolę najmocniej zaangażowanego wewnętrznie, a zarazem bezradnego świadka. Narracja niespodziewanie wrzuca widza w sam środek dramatycznej sytuacji fabularnej. Najpierw pokazuje się nam zakrwawione oblicze leżącego bohatera, a potem dopiero $\mathrm{z}$ jego perspektywy oglądamy to, co wcześniej tylko słyszeliśmy - gwałt niemieckiego żołnierza na kobiecie i jej zastrzelenie. Jest ona ułożona na brzuchu, a zatem możemy - wraz $\mathrm{z}$ bohaterem - obserwować jej twarz.

Tadeusz nie zamyka oczu ani nie odwraca głowy. Nie czyni też żadnego gestu, choćby samobójczej próby ratunku czy protestu. W ciszy poddaje się torturze patrzenia. Gdy Niemcy odchodzą, podczołguje się do trupa, jak się okazuje, bliskiej sobie osoby (dopiero później dowiadujemy się, że to żona) i delikatnie całuje jej głowę.

Smarzowski już na początku stara się formułować przekaz o jasnej dominancie znaczeniowej, symbolicznej i emocjonalnej, przekaz serio, a przy tym możliwie radykalny, naturalistyczny. Trzeba jednak zauważyć, że prawie pół wieku wcześniej niemal identyczną w treści, choć estetycznie odmienną scenę umieścił Andrzej Wajda w Popiołach (1965) według Stefana Żeromskiego. Chodzi rzecz jasna o scenę gwałtu na Helenie de With, a także jej samobójczej śmierci, w której zaledwie obserwatorem jest szamoczący się Rafał Olbromski. W centrum tych obrazów jest osobista klęska, zagłada, poczucie kontaktu z rzeczywistością jako źródłem trudnego do opisania bólu.

A jednak ani jeden, ani drugi twórca, prowadząc dalej narrację, nie nakręcili serii obrazów pogłębiających destrukcję świata głównego bohatera w jego zewnętrznym i wewnętrznym wymiarze. Szczególnie uniknął tego ten młodszy, a miał przecież lepsze wzory we współczesnym sobie kinie i udowodnione już twórcze możliwości. Przeciwnie, obdarzył Tadeusza wolą życia, a także mimo wszystko zaufaniem do własnego i cudzego człowieczeństwa. Nie odebrał mu wiary, mocno utrwalonej, choć dyskretnie manifestowanej. Stąd decyzja wejścia w nową rzeczywistość, otwarcia się na nowe impulsy witalne. Nie zabrałby broni, pieniędzy i dokumentów, które znalazł przy rozkładających się zwłokach niemieckiego żołnierza i nie poszedł z nimi do domu wdowy, 
gdyby trawiła go głęboka rozpacz, obojętność, poczucie rezygnacji albo gdyby opanował go nihilizm. Nie zobaczyłby w niej osoby potrzebującej pomocy, gdyby żył pragnieniem zemsty. Pozostał jednostką wewnętrznie zintegrowaną - aż do końca filmu. Spotkanie z Różą bynajmniej nie pobudziło go do aktywności. Ono było jej rezultatem.

Jego świat przestał istnieć. Nie było już małżeństwa, nie było żadnej rodziny (jedyny stryj znalazł się w gułagu pod Wierchojańskiem), nie było oddziału, nie było zwycięstwa czy choćby honorowej porażki, nie było domu ani własnego miejsca na ziemi. Szykował się świat na nowo i złowieszczo dla takich jak on skrojony. Nie było więc też najmniejszej pewności co do możliwości wejścia w jakiś cichy, usytuowany na marginesie tryb życia. A jednak po przespaniu się w domu Róży Kwiatkowskiej jej gość odnajduje w miasteczku adepta fryzjerstwa, który goli mu zbyt długą brodę, aby mógł wrócić bardziej schludny.

Pojawia się jednak pytanie, czy spotkanie z mazurską chłopką stało się w wewnętrznej logice jego życia rzeczywiście nowym początkiem? A może raczej jest to odnalezienie tego, co utracił? „Moją żonę zgwałcono i zabito prawie równocześnie. Mam się cieszyć, że nie żyje? Różę tyle razy gwałcono, że teraz umiera" - mówi jednym tchem do Władka, przybysza spod Wilna, pod koniec filmu[3]. Zastanawiająca jest łatwość, z jaką bohater wchodzi w nową relację, mimo bardzo świeżej rany. Należy rozumieć - oddając należne serwituty realizmowi - uwarunkowania tamtego czasu, który przyzwyczajał i w pewnej mierze znieczulał na najbardziej dramatyczne zdarzenia, a jednocześnie nakazywał na potrzeby tak bardzo zagrożonej, unieważnionej, poddanej presji zła pojedynczej egzystencji wyszarpywać wszystko, co niosło choćby cień wytchnienia i nadziei. Ale należy także rozumieć uwarunkowania filmowej konwencji melodramatu, która trochę pomaga w częściowym odpsychologizowaniu całej sytuacji. Dzięki niej bohaterowie okazują się przede wszystkim symbolicznymi figurami, tylko do pewnego stopnia przyobleczonymi w realistyczną pojedynczość.

Miłość Tadeusza jest czysta - to jedno z podstawowych założeń melodramatycznej konwencji. Nie ma w nim chęci zdominowania potrzebującej opieki kobiety, znalezienia za jej pośrednictwem swego miejsca na ziemi. „Dobrze, rozminuję i pójdę” - odpowiada mężczyzna na sugestię Róży, że chciałby przejąć majątek. Jego miłość wyraża się cielesną powściągliwością, delikatnością gestów lub ich powstrzymywaniem. Jeśli dochodzi do jakiegoś zbliżenia, to tylko z inicjatywy kobiety. Przenosi się owa miłość na poziom duchowego porozumienia, bliskiego przyjaźni. Kamera śledzi z uwagą ich twarze, ruchy rąk, nawet gdy leżą w łóżku, ogranicza nasze widzenie do tej perspektywy. Najgłębszym wyznaniem pozostaje tekst literacki czytany przez mężczyznę w obliczu zbliżającej się śmierci umęczonej kobiety. Nie ma w jego miłości dystansu, pozy czy gry - widać to w scenach, gdy cierpi w samotności. Jest ona zmaganiem się z materią świata, dla którego staje się niechcianym

[3] Wszystkie cytaty ze ścieżki dźwiękowej filmu

Róża. 
ciężarem albo skandalem i nigdy ta materia (nawet okrutne śledztwo czy gułag) nie odnosi nad nią zwycięstwa. Mimo najdramatyczniejszych przejść i największych przeszkód nie podlega ona śmierci, jest trwała, wierna, nieprzemijająca. Film się kończy, a ona zostaje. Róża, poprzez tożsamość losu, staje się nową Anną (takie imię zabitej żony Tadeusza podaje znajomy lekarz), zaś Jadwiga - nowym wcieleniem Róży, której postać na miejscu córki widzi bohater w momencie ślubu. Ta ciągłość tożsamości między kobietami jest ważnym powodem wspominanej powierzchownej mazurskości tytułowej bohaterki. Jej postać musiała wpisać się w przestrzeń, którą wyznaczył domniemany wizerunek poległej w powstaniu żony, nie mogła być nazbyt odmienna.

Miłość Róży, a może raczej Anny-Róży-Jadwigi, staje się odbiciem doskonałej miłości mężczyzny. W filmie okres wykluwania się tego uczucia jest bardzo krótki. Już po powrocie z miasteczka Tadeusz nieznacznie, ale jednocześnie znacząco, się do niej uśmiecha. Ona odpowiada niedługo potem - w scenie $z$ pęknięciem spodni, a jeszcze bardziej w scenie wybuchu miny, w której pojawia się jej wykrzyczany po niemiecku monolog. Już mniej więcej od dwudziestej siódmej minuty ponadpółtoragodzinnego filmu kończą się wszelkie kanciastości, niedopasowania, napięcia między dwojgiem bohaterów. Miłość staje się pełna, choć tak bardzo niecielesna. Trwa w konwulsyjnym rytmie scen arkadyjskich (jazda rowerem, bielenie ścian, przejażdżka po jeziorze) w większości z nich ma swój udział także Jadwiga - i zdecydowanie bardziej rozbudowanych dramatycznych scen ratowania $z$ opresji, dochodzenia do siebie i rozważania zagrożeń.

Zresztą Jadwiga również bez większych oporów przyjmuje obecność Tadeusza w domu, u boku matki, w małżeńskim łożu rodziców. A pojawia się on przecież bardzo krótko po śmierci ojca. Jedynie w pierwszej scenie dialogowej na prośbę mężczyzny, by mówiła po polsku, odpowiada ostro: „Mein Papa sprach Deutsch”. Później następuje bezwarunkowa akceptacja. Zalana łzami od razu godzi się na prośbę matki, by wziąć z nim ślub, i - choć nie jest do tego zobowiązana - czeka na jego powrót $\mathrm{z}$ zesłania. Znosi upokorzenie wydziedziczenia, pozostając we własnym domu osobą na marginesie, co świetnie wizualizuje kilkusekundowe ujęcie zmagania ze świnią z sekwencji finałowej. Jej wypowiedziana gestami i cierpliwością miłość stwarza gotowość na pełne oddanie siebie i zaufanie, które stają się rzeczywistością w chwili pojawienia się byłego już więźnia.

Sprowadzenie Róży wyłącznie do konwencji melodramatycznych byłoby oczywiście piramidalnym nieporozumieniem. Świadczy o tym już powyższy opis, który, wskazując na spełnienie się wielu definicyjnych wyróżnień tego gatunku, jednocześnie uzmysławia tych wyróżnień przekroczenia. Przekroczenie stanowi drastyczność przedstawień, poetyka naturalizmu eliminująca sentymentalność, łzawość czy patos, a także podobnie oddziałująca niezwykle powściągliwa gra aktorska. Przekroczenie to interioryzacja uwarunkowań historycznych, rozległe konotacje znaczeniowe i kulturowe. Reżyser potraktował 
konwencję gatunkową jako swego rodzaju poręczny stelaż, na którym można budować przekaz, mimo swej brutalności możliwy do przyjęcia dla stosunkowo szerokiego grona odbiorców.

Elementem takiego stelażu jest bez wątpienia postać tego trzeciego, mniej szczęśliwego kochanka, enkawudzisty Wasyla. To kreacja nader konwencjonalna, choć dzięki umiejętnościom aktora i poetyce filmu wiarygodna. Mamy tu zatem pewną wersję człowieka zza wschodniej granicy, dzikiego, prymitywnego, niedojrzałego, który pełni funkcję charyzmatycznego przywódcy bandy gotowych na wszystko zbrodniarzy, skłonnego do swawoli, używania przyjemności zmysłowych we wszelkich formach i do najdalej posuniętego okrucieństwa, a jednocześnie człowieka zdolnego do silnych emocji. Są to uczucia, których nie potrafi on odróżnić i oddzielić od najzwyczajniejszych żądz i dlatego nie waha się używać przemocy dla zaspokojenia własnych pragnień. W dorobku tego samego aktora znajduje się zresztą zbliżona rola. Tuż przed realizacją Róży zagrał on bolszewickiego sołdata, gwałciciela, okrutnika, pijaka, ale człowieka niepozbawionego prostych uczuć, w serialu 1920. Wojna i miłość Macieja Migasa (2010). Co interesujące, tam i tu postać ta ginie z ręki krzywdzonej kobiety. Tak źle nie skończył nawet jeden $z$ jego dawnych protoplastów - o ileż łagodniejszy w swym wyrazie Sienkiewiczowski Bohun. To nawiązanie ma sens o tyle, że przywołuje literaturę popularną z jej głęboko zakorzenioną mitologią. Przywołuje również postać namiestnika husarskiej chorągwi księcia Jaremy, ale to już w trochę odmiennym kluczu personalnych odniesień.

Wydaje się, że lepszym niż niewątpliwie uzasadnione odwołanie do konwencji melodramatu kluczem do odczytania obrazu relacji Tadeusza i Róży będzie przywołanie obecnej przede wszystkim na gruncie literatury rzeczywistości mitycznej, kryjącej się pod pojęciem miłości romantycznej. Można by powiedzieć, że jest to podążanie do źródła, gdyż melodramat (także filmowy) w zasadzie jest zbanalizowaną, dostosowaną do potrzeb kultury popularnej postacią tejże[4]. Przy czym miłość romantyczna jawić się tu powinna zarówno jako swoisty i arcyważny element kultury epoki, od której przyjęła nazwę, jak i szerzej - jako fenomen obecny w kulturze europejskiej od średniowiecza. Na jej trop sprowadza świadomość niewystarczalności kategorii melodramatu, owych wspomnianych wyżej przekroczeń. Ale nie wyłącznie. Szczególnego znaczenia nabierają tutaj finałowe partie filmu, które chwieją poczuciem realizmu i rozszerzają perspektywę przekazu poprzez obrazy, gesty i słowa bezpośrednio ewokujące przestrzeń transcendencji i w efekcie silnie wpływają na odbiór całości dzieła.

Cechy miłości Tadeusza i Róży (Anny-Róży-Jadwigi), które zostały już przywołane i które doprowadziły nas do zagadnienia melodramatyczności, wpisują się także w ową romantyczną parantelę, uzyskując głębsze uzasadnienie i sens. Wewnętrzna doskonałość, niezmienność,

[4] M. Piwińska, Miłość, w: Słownik literatury polskiej

XIX wieku, red. A. Kowalczykowa, J. Bachórz, wyd. 3,

Ossolineum, Wrocław 2002, s. 546. 
czystość, intensywność, pełnia, jej pierwszoplanowa, nadrzędna ranga, jej życiodajność w nieludzkiej czasoprzestrzeni świata - to charakterystyka, która wprost realizuje słownikową definicję miłości romantycznej. Podobnie zresztą jak dwie następne, a wspominane już, cechy: apsychologizm oraz degradacja sfery zmysłowej.

Romantyczny rodowód pierwszej z nich znakomicie ilustruje uwaga Marty Piwińskiej: „Romantyków bardziej interesuje w miłości znak losu niż tajemnica wzajemnego pociągu oraz psychologia uczucia. Raczej miłość-fatum niż miłość-eros"[5]. Ten postulat w pełni realizuje Róża. Nie ma w niej, jako się rzekło, meandrów międzyludzkiej komunikacji, zmiennych emocji, odruchów buntu przeciw sile uczucia. Jest przemożna presja historii kształtującej fatalne (nie do końca?) obroty zdarzeń.

Druga - dotykająca kwestii cielesności - brzemienna w wielorakie skutki, pojawia się oczywiście nie jako rezultat wolnego wyboru kochanków czy też wcielenie konwencji, ale wynika raczej z okoliczności zewnętrznych, z owej fatalnej historii. Wielokrotnie zgwałcona, zmaltretowana fizycznie i psychicznie Anna-Róża nie jest w stanie funkcjonować w sferze zmysłowej w sposób naturalny. Choć nie dzieje się tak, że nie funkcjonuje w ogóle. Jako przestrzeń miłosnego połączenia pozostaje jednak nade wszystko przestrzeń duchowa, w optyce romantycznej postrzegana jako jedynie warta zabiegów. Wyrazem tej bliskości duchowej staje się poczucie zjednoczenia, przyjaźni czy nawet pokrewieństwa[6]. Warto zwrócić uwagę na pierwszą część urywka powieści Pierre’a Lotiego, który w scenie poprzedzającej obraz spoczywającego w trumnie ciała Róży odczytuje umierającej kobiecie poruszony Tadeusz: „Więc jest tak: gdy miłość rośnie i dochodzi do pragnienia nieskończonego trwania, lub gdy przyjaźń staje się taka głęboka, że lękać się zaczyna końca [...]"[7]. A zatem - obok innych znaczeń - jest tu bardzo silne skojarzenie miłości i przyjaźni. Chodzi więc nie tyle o - w relacji między tymi dwojgiem - potężną, ślepą siłę emocji, ile o ugruntowane duchowo - mówiąc po mickiewiczowsku - „czucie”. Miłość staje się trwałym przymierzem zmierzającym do przekroczenia granic natury, co ma swoje ogromne konsekwencje w kreacji obrazu tejże miłości i bardzo wiąże ją ze świadomością romantyczną.

Katastrofa to centralne pojęcie w logice romantycznego połączenia dusz. Śmierć, martwe ciało jednego lub obojga kochanków, grób stają się najczęstszym wizerunkiem nieuniknionej i fatalnej klęski. A tenże kres bierze się z faktu, iż miłość jest formą buntu przeciw światu. Źródła romantycznego buntu były, rzecz jasna, charakterystyczne dla owej epoki w jej obyczajowym, społecznym i intelektualnym wymiarze.

[5] Ibidem, s. 548.

[6] Romantyczni kochankowie, np. u Mickiewicza czy Musseta, zwykli nazywać się bratem i siostrą na znak niezbywalnego pokrewieństwa duchowego. M. Piwińska, op. cit.
[7] P. Loti, Zjawa Wschodu, tłum. H. Lipszycówna, Biblioteka Dzieł Wyborowych, Warszawa 1925, s. 22. 
Miał on w imię wartości absolutnych, transcendentnych złamać krępujące, a nawet niszczące, konwencje i uwarunkowania „codziennego życia”, podziałów społecznych, upadłej natury, utylitarnej moralności, skupionego na powierzchownej przyjemności libertynizmu. Finał tego buntu musiał okazać się tragiczny, ale też nie chodziło w nim w istocie o urzeczywistnienie się ziemskiego szczęścia, ale o wewnętrzną przemianę, doświadczenie innego świata.

Zakończona pochowaniem Róży i kaźnią Tadeusza miłość także była buntem, zakończonym klęską - przynajmniej w planie doczesnej realności. Był to sprzeciw wobec świata ludzkiego zdegradowanego do najniższego poziomu, do oddziaływania najprymitywniejszych instynktów: żądzy bezwzględnej dominacji, żądzy krwi, żądzy posiadania (także czyjegoś ciała), strachu itp. Miłość - a tym bardziej miłość podlegająca takiej jak to ma miejsce w Róży sublimacji - w tym zdegenerowanym, zanarchizowanym świecie staje się mocnym, choć zarazem prawie bezsilnym w sensie praktycznym, znakiem sprzeciwu, zjawiskiem $\mathrm{z}$ całkowicie innego porządku.

Ale nie chodzi tylko o chaos, degradację, anarchię i triumf zdziczałej natury. Świat bowiem, w którym pojawia się miłość dwojga bohaterów, zmierza już ku nowemu porządkowi, stopniowo nań nakładanemu. I w tym nowym porządku, wprowadzanym przez sowiecką władzę (także polskimi rękami), staje się ona tym bardziej niemożliwa. Jest wbrew temu porządkowi ze względów politycznych (pochodzenie Róży, biografia Tadeusza), ale może jeszcze bardziej poprzez swą nieprzystawalność do uprzedmiatawiającej człowieka ideologii oraz pragmatyki nowej władzy. Okazuje się fenomenem duchowym pozostającym poza kontrolą. Decyzja kobiety o niepodpisaniu deklaracji polskości, a także odrzucenie przez Tadeusza możliwości współpracy z UB, to formy oporu, które nie wynikają już z instynktownej obrony, jak walka $z$ napadającymi dom Mazurki bandytami. To, wydawałoby się, świadomy bunt każdego $\mathrm{z}$ nich $\mathrm{z}$ osobna. Ale jest to przecież $\mathrm{w}$ istocie bunt jednorodny, wyrastający z duchowej wspólnoty bohaterów, którzy się nawzajem wspierają, przekazują sobie siłę. „A ty byś to zrobił?” - tak Róża ucina namowy Tadeusza do podpisania deklaracji ze względów praktycznych (utrzymanie gospodarstwa, los córki). Bunt ten w oczywisty sposób - zgodnie z logiką miłości romantycznej - implikuje katastrofę. Gdyby zdecydowali inaczej, ich miłość miałaby wszelkie szanse uratować się w wymiarze ziemskiego szczęścia. Mogłaby nawet stać się usprawiedliwieniem przyjętych zobowiązań. Ich miłość jednak ocala przede wszystkim w sensie duchowym i dlatego nie mieszczą się $\mathrm{w}$ jej istocie takie rozwiązania.

O miłości romantycznej można powiedzieć, iż ma ona charakter transcendentny, wymiar kosmiczny, że jest znakiem rzeczywistości wyższej[8]. Ostatnie ujęcie - z tak lubianym przez Smarzowskiego, różnie w różnych filmach sfunkcjonalizowanym, podniesieniem kamery

[8] M. Piwińska, op. cit., s. 549. 
umieszczonej na kranie - wizualizuje takie rozumienie w sposób wyrazisty. Oglądamy dwoje bohaterów, Tadeusza i wspartą na nim Jadwigę, w radykalnym geście opuszczania codzienności, świata mniejszych i większych spraw ludzkich, i wkraczania w niczym nieograniczoną (na ile pofałdowany pejzaż mazurskich łąk, jezior i lasów pozwalał na takie rozwiązanie) i odludną scenerię, w której - jak to ujął Norwid w znanym z Popiołu i diamentu Wajdy wierszu o wizycie w piekle „[...] znad kulbaki / Patrząc, firmament cały?... okolicą!”[9]. Tadeusz Sobolewski ostrożnie formułuje swoją sugestię dotyczącą owej sceny: „W planie symbolicznym losy tej pary, ich spotkanie, cierpienie, miłość, niosą coś na kształt odkupienia"[10]. Znajdujemy w tych słowach potwierdzenie wyraźnego przełamania horyzontu tu i teraz.

Kinga Dunin w trakcie dyskusji na temat Róży martwi się, iż Tadeusz zabiera Jadwigę z jej domu „nawet bez majtek na zmianę”[11]. Podobnie jak jej interlokutorki nie zauważa, iż już od sceny ślubu tych dwojga - przede wszystkim dzięki wizualnej kreacji poszczególnych ujęć oraz montażowi zastosowanemu w sekwencji przesłuchania - znajdujemy się w przestrzeni symbolicznej, nie odtwarzającej, lecz syntetyzującej doświadczenie rzeczywistości.

Róża ubrana i uczesana na sposób lat nastych XXI wieku zastępuje swoją córkę w scenie małżeńskiego pocałunku, zakłócając porządek mimesis i potwierdzając jednocześnie wskazaną wyżej tożsamość trzech postaci kobiecych. Zetknięcie nowożeńców z brutalną przemocą, upostaciowaną przez funkcjonariuszy UB, oczekujących na Tadeusza pod kościołem, a także zetknięcie powracającego z zesłania posiwiałego bohatera $z$ Mazurami wsiadającymi do pociągu, aby odjechać na zawsze, oraz z Władkiem i jego rodziną, którzy podczas jego nieobecności zajęli gospodarstwo Róży, to esencjonalne obrazy spotkania ze światem wypełnionym przemocą, niesprawiedliwością, krzywdą, strachem, brakiem nadziei, egoizmem, z rzeczywistością ludzi pozbawionych woli lub zdolności wydobycia się $\mathrm{z}$ infernalnej spirali zdarzeń. Odejście bohaterów staje się gestem porzucenia tej skażonej przestrzeni, rezygnacji z pracy nad jej choćby drobną przemianą, rezygnacji z kontynuowania sprzeciwu choćby poprzez trwanie. To gest antypragmatyczny, kreujący sferę wolności poza niezwykle dotkliwym tu i teraz, szukający poza nim wyzwolenia, odrzucający ograniczenia albo nawet niewolę doczesności.

Ostry podział między realną codziennością a sferą czysto duchową, w której to dopiero można zrealizować wartości prawdziwie ludzkie, mieści się w kręgu wyobrażeń romantycznych, manifestujących się w losach kochanków. Sens zakończenia Róży, który Sobolewski rozeznawał jako „coś na kształt odkupienia”, można byłoby rozumieć bardziej

[9] C.K. Norwid, W pamiętniku, w. 74-75.

[10] T. Sobolewski, Wybitny film „Róża”. Pole minowe historii, „Gazeta Wyborcza” 2 lutego 2012, nr 27, s. 10. [11] Dunin, Szczawińska, Wiśniewska: Pan Tadeusz na Mazurach. Rozmawiają Kinga Dunin, Weroni- ka Szczawińska i Agnieszka Wiśniewska, „Krytyka Polityczna" [online], 7 marca 2012 [dostęp: 17 lutego 2015], <http://www.krytykapolityczna.pl/en/artykuly/ serwis-kulturalny/20130710/dunin-szczawinska-wisniewska-pan-tadeusz-na-mazurach>. 
ściśle jako symboliczne przekroczenie wymiaru doczesności, odniesienie miłości do bliżej nie zdefiniowanego uniwersum wieczności. To figura wyobraźni znana bardzo dobrze tradycji literackiej - tradycji romantycznej, ale w sensie zdecydowanie szerszym niż odniesienie do konkretnej epoki. Krach miłości w planie życia na ziemi i jej trwanie po śmierci, jej zdolność do transcendencji uczestniczących w niej bytów jest motywem w kulturze Zachodu ufundowanym przez literackie inkarnacje romansu Tristana i Izoldy[12]. Obraz wyrastającego z grobu rycerza i łączącego się z grobem królowej bujnego i pachnącego krzewu głogu pochodzi co prawda od Josepha Bédiera, a więc z roku 1900, lecz wyraża istotę zawartej w legendzie koncepcji miłości[13]. Koncepcja ta w mniej lub bardziej spektakularny sposób przejawia się w historiach Heloizy i Abelarda, Romea i Julii, potem w romantycznych Hymnach do nocy Novalisa, Mickiewiczowskiej Romantyczności, gotyckich tekstach Emily Brontë, Ernsta Theodora Amadeusa Hoffmana czy Edgara Allana Poe. Funkcjonowała w niemal współczesnych opowiadaniach - Happy endzie Borysa Akunina czy Gustawa Herlinga-Grudzińskiego Cmentarzu południa. Opowiadaniu otwartym. Znana jest też z oryginalnych scenariuszy filmowych - np. z Jasminum (2006) Jana Jakuba Kolskiego. Najbardziej może jednak bliskie filmu Smarzowskiego byłoby zakończenie Mistrza i Małgorzaty Michaiła Bułhakowa, bliskie ze względu na kontekst historyczny zestawiający jednostkę ludzką z totalitarną maszynerią społeczną, jednostkę zdolną do transcendencji z maszynerią ową zdolność brutalnie niszczącą[14].

Motyw ten wprowadza autor Domu złego w sposób dyskretny, niejednoznaczny, otwarty. W ogóle zresztą romantyczne konotacje Róży pozostają raczej w ukryciu. Forma filmowa odsyła widzów przede wszystkim ku amerykańskim konwencjom gatunkowym (np. ku westernowi, zwłaszcza temu spod znaku Sama Peckinpaha), podstawowe tematy - wojenne gwałty i ciężki los Mazurów - ku mocno zideologizowanym dyskursom poprawnościowym, emancypacyjnym, pacyfistycznym i skupionym wokół problemów cielesności, obrazy przemocy zaś - ku współczesnej destrukcyjnej wizji świata jako miejsca niszczącej alienacji i braku trwałych wartości, ku estetyce skrajnego naturalizmu pozbawionego odniesień transcendentnych. Dopiero bardziej wnikliwe spojrzenie na dzieło ujawnia jego autonomiczność wobec „ducha czasu”, zanurzenie w ciągłość kulturowych przedstawień, niepolegające na użyciu cytatu, grze czy dekonstruujących przetworzeniach, lecz na autentycznym - co nie znaczy bezdyskusyjnym zakorzenieniu.

[12] Wyprawa Orfeusza do krainy śmierci kończy się przecież fiaskiem.

[13] Motyw krzewu przejęty został z dwunastowiecznego poematu Marii z Francji Wiciokrzew. J. Gorecka-Kalita, Wstęp, w: Tristan i Izolda, Ossolineum, Wrocław 2006, s. VI.

[14] Źródła i obecność motywu miłości po śmierci w literaturze europejskiej szerzej omawia Natalia Leman w artykule Motyw miłości po śmierci - czyli co literatura zawdzięcza Celtom. Garść subiektywnych uwag na marginesie literatury światowej (w: Miłość romantyczna jako figura wyobraźni, red. B. Płonka-Syroka, E. Rudolf, Oficyna Wydawnicza Arboretum, Wrocław 2009, s. 63-78). 
Właśnie obraz relacji dwojga głównych protagonistów czyni wyłom w automatycznie kreowanych interpretacjach Róży. Konsekwentnie wciela on bowiem wielki mit miłości romantycznej, współcześnie funkcjonujący zazwyczaj w produkcjach filmowych przepojonych trywialnym sentymentalizmem, skierowanych do mało wymagającego odbiorcy, uznawanych za nieistotne w sensie artystycznym, a przy tym konserwatywne ideowo (a to nieomalże inwektywa). Wcielając zaś ów mit, odsyła ku odmiennej w swej treści, a jeszcze bardziej w charakterze, rzeczywistości kulturowej, rzeczywistości wewnętrznie zintegrowanej i określonej tożsamościowo, samą siebie traktującej z powagą.

Kultura jest istotnym tworzywem miłości[15], a już na pewno jej języka czy sposobu jej pojmowania i postrzegania. Dlatego też przez analizę obrazu miłości można rozpoznać źródłową przestrzeń kultury, z której pochodzi cały przekaz. W przypadku Róży stanowi ją przede wszystkim romantyzm. Stwierdzenie takie domaga się dalszych uzasadnień. Miejsce na nie znajdzie się już jednak w innych tekstach. Potrzeba go bowiem niemało. 